\title{
Influence of Plant Diversity on the Numerical Response of Eriopis connexa (Coleoptera: Coccinellidae) to Changes in Cereal Aphid Density in Wheat Crops
}

\author{
María C. Tulli, Dora M. Carmona, and Ana M. Vincini \\ UI EEA Balcarce, INTA-FCA, UNMdP, Zoología Agrícola, Ruta 226, Km 73,5, Balcarce 7620, Buenos Aires, Argentina \\ Correspondence should be addressed to María C. Tulli; maricel_46@hotmail.com
}

Received 30 June 2013; Revised 20 October 2013; Accepted 18 November 2013

Academic Editor: Jean-Guy Godin

Copyright @ 2013 María C. Tulli et al. This is an open access article distributed under the Creative Commons Attribution License, which permits unrestricted use, distribution, and reproduction in any medium, provided the original work is properly cited.

Cereal aphids cause economic injury to wheat crops. In Argentina, Eriopis connexa is an indigenous ladybird. In the present study, the numerical response of E. connexa to changes in aphid density on wheat crops with high and low plant diversity was investigated. The study was carried out in Balcarce, Buenos Aires, Argentina, from September to December 2007 and 2008, on two wheat crops with either a higher plant diversity (HPD) with refuge strips or a lower plant diversity (LPD) without refuge strips. Crops were sampled every week and the abundance of aphids and E. connexa was recorded. The dominant aphid species were Schizaphis graminum, Metopolophium dirhodum, and Sitobion avenae. Eriopis connexa showed a linear increase in the numerical response to an increase in aphid density, which varied in space and time. The abundance of E. connexa increased in relation to the crop development and aphid population and was higher in the HPD than in the LPD system. This predator increased its reproductive numerical response only in 2008, with a significant liner response in the HPD system. This suggests that the potential of E. connexa as a predator of cereal aphids also increases directly in proportion to landscape vegetal diversity.

\section{Introduction}

Cereal aphids (Hemiptera: Aphididae) are among the most important pests on wheat crops in the world, since they are found in all temperate regions and cropping systems and have the potential to reduce yields $[1,2]$. Depending on the species and the year, aphids can cause economic damage by direct feeding, by injection of toxins that cause yellowing, stunted growth, curled leaves, and malformations, or by transmission of viruses that cause indirect plant injury [1-4]. As a result, aphid damage in wheat crops causes losses in yields and grain quality [5-11].

Insecticide application is the strategy selected by farmers to control aphids in wheat crops around the world. However, the frequent use of a wide range of pesticides has caused many side-effects, including loss of biodiversity, secondary pest outbreaks, the development of insect resistance to insecticides, residual toxicity, and suppression of natural enemies [12-14]. As a consequence, promoting the activity of predators and parasitoids in growing systems to maintain aphid populations below the economic injury level remains a desirable goal [15]. Several groups of natural enemies can control aphid populations in wheat crops, such as parasitoid wasps (Hymenoptera: mainly Aphidiidae) and a very large number of predators such as hoverfly larvae (Diptera: Syrphidae), lacewing larvae (Neuroptera: Chrysopidae), and ladybird adults and larvae (Coleoptera: Coccinellidae) [16, 17].

Aphidophagous ladybirds are important predators of aphids in agricultural crops and have been considered as biological control agents, given their ability and voracity to feed on a wide range of prey [18]. In Argentina, some important ladybird species are Eriopis connexa (Germar), Hippodamia convergens (Guérin-Méneville), Coleomegilla quadrifasciata (Schöenherr), Adalia bipunctata (Linnaeus), and Harmonia axyridis (Pallas) [19]. In Balcarce, Buenos Aires province, Argentina, Martinoia [20] determined that the dominant species on potato crops is the exotic $H$. axyridis, introduced from Asia, and E. connexa, an indigenous coccinellid species with an exclusive natural distribution in South America [21]. Adults of E. connexa are 3-4 mm length and have a hairless 
oval body and the elytra are black with twelve red and white spots [22, 23].

Pest suppression by aphidophagous ladybirds in agricultural crops is affected by primary factors, such as the combination of prey and predator densities. This results in two effects: each predator increases its consumption rate when it is exposed to a higher prey density (functional response), and predator density increases when the prey density also increases (numerical response). However, the term "numerical response" comprises two different mechanisms: a higher rate of predator reproduction when prey is abundant, a "reproductive response," and an attraction of predators to prey aggregations, an "aggregational response" [24].

Like many natural enemies, adult coccinellids are transient predators, foraging within several habitats during the growing season [25]. For this reason, their diversity and abundance are expected to depend on both the abundance of prey within crop habitats and the structure and composition of the surrounding landscape [24]. It has been proven that habitat features, such as relative humidity, plant density, abundance of alternative foods, and other resources provided by plant diversity of the surrounding crops, can influence the spatial distribution of coccinellids $[17,26,27]$ and other natural enemies in agricultural landscapes [28-34]. Characteristics of the agricultural landscape might influence the numerical response of coccinellids. However, the role of plant diversity in determining the numerical response of native coccinellids in wheat crops in Argentina has not been investigated. Therefore, the main objective of the current study was to characterize the numerical response of E. connexa to changes in the aphid density on wheat crops, with or without the introduction of a refuge strip to increase plant diversity.

\section{Materials and Methods}

2.1. Study Site: Plant Diversity Management. The experiment was carried out in wheat crops grown with two different field management regimes located at the Integrated Unit of the Faculty of Agronomy, Mar del Plata National University and Balcarce Experimental Extension of the National Institute of Agricultural Technology (UIB) $\left(37^{\circ} 45^{\prime} \mathrm{S} 58^{\circ} 18^{\prime} \mathrm{W}\right)$, from August to December 2007 and 2008. The site was established in 2004 and comprised two plots of $6,400 \mathrm{~m}^{2}$ each being $20 \mathrm{~m}$ apart, with different management systems and representing two environments: a crop with a high plant diversity (HPD) with the introduction of refuge strips, and a crop of low plant diversity (LPD) without refuge strips. Refuges consisted of $3 \mathrm{~m}$-wide strips [30] and 10 perennial flowering and aromatic species were planted in the central half meter: Thymus vulgaris, Melisa officinalis, Coriandrum sativum, Artemisia absinthium, Lavandula officinalis, Rosmarinus officinalis, Ruta graveolens, Salvia officinalis, Origanum vulgare, Calendula officinalis, Chrysanthemum leucanthemum, and Helianthus annuus. In addition, Medicago sativa was seeded for $1 \mathrm{~m}$ on each side of the refuge strips [20]. These plant species were selected to provide pollen, nectar, overwintering refuges, and potential prey resources for natural enemies. Two small plots of $1,600 \mathrm{~m}^{2}(40 \mathrm{~m} \times 40 \mathrm{~m})$ of each environment were selected for our study and were $60 \mathrm{~m}$ apart (Figure 1). Each plot was sown with wheat (Klein Chajá) in $17.5 \mathrm{~cm}$ rows, at a density of 350 seeds $/ \mathrm{m}^{2}$ on 10 August 2007 and 6 August 2008. During the study, there were no applications of herbicide or insecticide to the crop or refuge strip.

2.2. Sampling Procedure. Natural populations of aphids and coccinellids were sampled weekly from 5 September to 26 December 2007, and from 2 September to 22 December 2008. Nine sampling sites consisting of four plants were randomly selected for each sampling date. On each sampling date, we quantified all the aphids and coccinellids present by carefully inspecting each plant. Larval stages of coccinellids that could not be identified were taken to the Service and Research Unit of the Agricultural Zoology Laboratory (LISEZA) at the UIB, and reared to adulthood in a growth chamber, under 16L: $8 \mathrm{D}$ light conditions; $22 \pm 2^{\circ} \mathrm{C}$ temperature, and $80 \%$ relative humidity. Emerging adults were identified using an Olympus 160x stereoscopic microscope and the taxonomic key of Saini and de Coll [22], and the entomological collection of insects of LIZEZA was used for reference. We investigated the numerical response of predators by plotting aphid density against concurrent variation in adults and larvae of $E$. connexa recorded in the same year, for each management system.

2.3. Statistical Analysis. Our primary analysis applied a generalized estimating equations approach, which is appropriate for longitudinal data because it allows for within subject repeated measures examination of change over time as well as correction of variance estimates for correlated data within subject. Aphid and coccinellid abundance was modeled using a negative binomial error distribution and a log-link function, specifying an exchangeable working correlation structure, which provided a good fit to the data. For each environment, the Wald Statistics using Type III empirical standard error analysis was used to test differences between means $[35,36]$. To determine if a relationship existed between the abundance E. connexa and the abundance of aphids, a regression model was fitted. Then, an analysis of covariance (ANCOVA) was performed to compare between slopes of the regression lines between treatments [36]. All statistical tests were considered significant at $P<0.05$.

\section{Results}

3.1. Species Composition and Seasonal Abundance of Aphids and Coccinellids on Wheat Crops with a High or Low Plant Diversity. The English grain aphid Sitobion avenae (F.), the rose-grain aphid Metopolophium dirhodum (Walker), and the greenbug Schizaphis graminum (Rondani) were the most frequently recorded aphid species throughout the cerealgrowing season. Sipha maydis (Passerini) was also identified, but its abundance was very low and was limited to a few plants surrounding the plot. The English grain aphid was the last species to colonise wheat each season and the most abundant species (Table 1; Figure 2). 

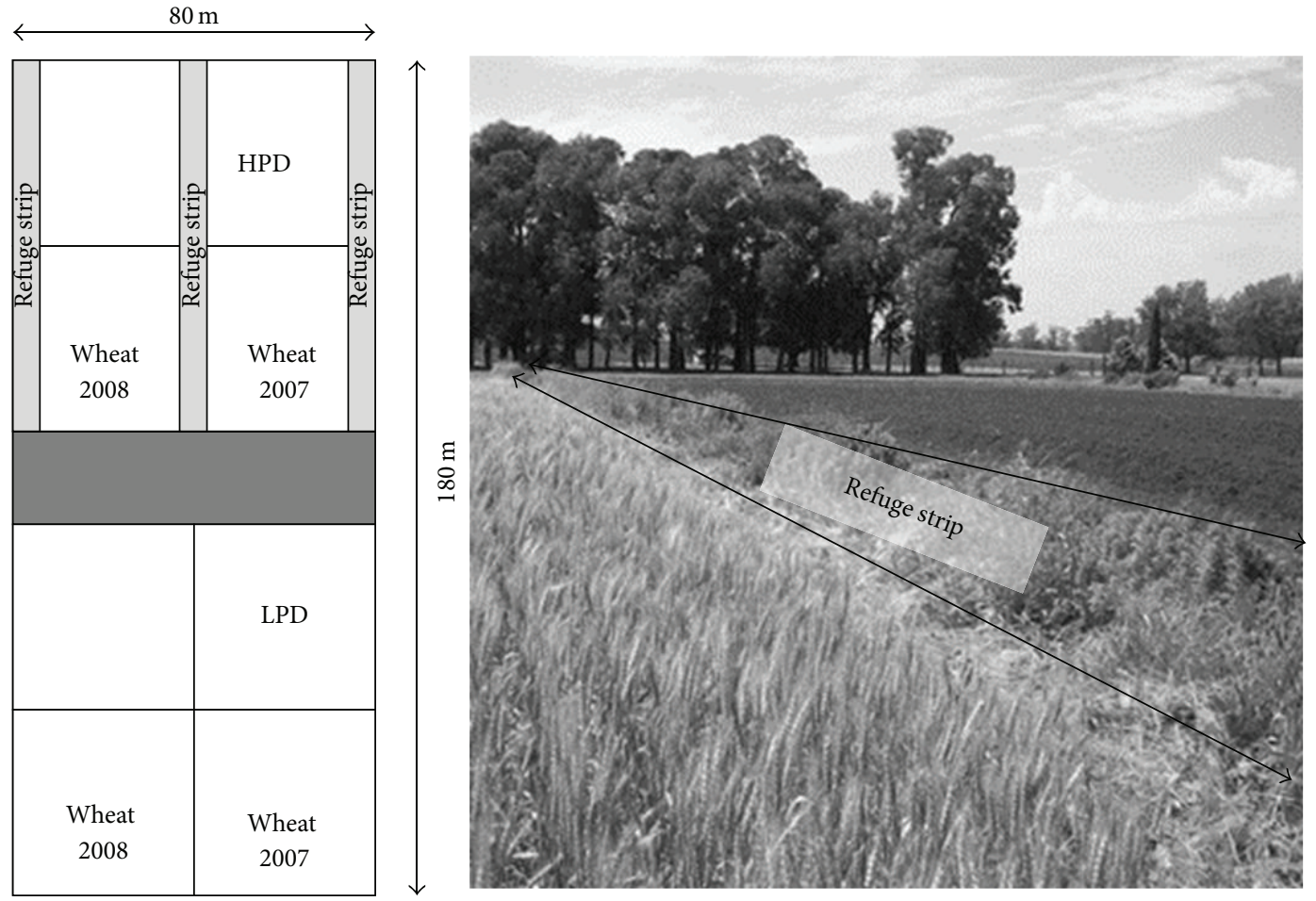

FIGURE 1: Representative plot to explain the layout of the two treatments of wheat crops with a high plant diversity (HPD) and low plant diversity (LPD) in 2007-2008. See text for a description of the experimental design.

TABLE 1: Total and relative abundance of aphids on wheat crops with a high (HPD) and low plant diversity (LPD). Balcarce, 2007 and 2008.

\begin{tabular}{|c|c|c|c|c|c|c|c|c|}
\hline & \multirow[b]{2}{*}{ Systems } & \multicolumn{2}{|c|}{ Schizaphis graminum } & \multicolumn{2}{|c|}{ Metopolophium dirhodum } & \multicolumn{2}{|c|}{ Sitobion avenae } & \multirow{2}{*}{ Total $(n)$} \\
\hline & & $\begin{array}{c}\text { Total abundance } \\
\text { (no.) }\end{array}$ & $\begin{array}{c}\text { Relative } \\
\text { abundance (\%) }\end{array}$ & $\begin{array}{c}\text { Total abundance } \\
\text { (no.) }\end{array}$ & $\begin{array}{c}\text { Relative } \\
\text { abundance (\%) }\end{array}$ & $\begin{array}{c}\text { Total abundance } \\
\text { (no.) }\end{array}$ & $\begin{array}{c}\text { Relative } \\
\text { abundance (\%) }\end{array}$ & \\
\hline \multirow{2}{*}{2007} & HPD & 43 & 16,67 & 89 & 34,50 & 126 & 48,84 & $258^{\mathrm{a}}$ \\
\hline & LPD & 56 & 15,38 & 128 & 35,16 & 180 & 49,45 & $364^{\mathrm{b}}$ \\
\hline \multirow{2}{*}{2008} & HPD & 82 & 17,05 & 152 & 31,60 & 247 & 51,35 & $481^{c}$ \\
\hline & LPD & 102 & 17,09 & 188 & 31,49 & 307 & 51,42 & $597^{\mathrm{d}}$ \\
\hline
\end{tabular}

Mean values followed by the same letter indicate no significant differences according to the LS means multiple range test at $P<0.05$.

There were significant differences in cereal aphid populations among the two management systems both in 2007 and 2008, with most aphids being found in the LPD area $\left(F_{1,18}=8.8, P<0.01\right)$. There was no effect of weeks $\left(F_{15,18}=\right.$ 15.07, N.S), and between years, aphid abundance was significantly higher in 2008 than in $2007\left(F_{1,18}=9.08, P<0.01\right)$. The interaction term was nonsignificant $\left(F_{1,18}=3.77\right.$, N.S $)$. The most abundant aphidophagous coccinellid species in wheat crops was E. connexa (85.76\%), followed by H. axyridis (10.68\%), Coccinella ancoralis (Germ.) (1.48\%), Scymnus argentinicus (Weise) (1.04\%), and Hyperaspis festiva (Mulsant) (1.04\%).

In contrast to aphid populations, most $E$. connexa individuals were found in the HPD area $\left(F_{1,18}=12.08, P<0.01\right)$. There was no effect of week $\left(F_{15,18}=13.5\right.$, N.S $)$, and between years, the abundance of $E$. connexa was significantly higher in 2008 compared to $2007\left(F_{1,18}=4.86, P<0.05\right)$. The interaction term was significant $\left(F_{1,18}=5.35, P<0.05\right)$.
The aphid population densities in 2007 and 2008 increased progressively from October through November and then declined suddenly coincident with the large increase in E. connexa and plant physiology changes, close to physiological maturity (Figure 3). Adults of E. connexa increased in abundance in relation to the development of the crop and aphid abundance, which reached its initial highest density at the end of October, after an increase in the abundance of Metopolophium dirhodum in 2007 and with the increase in S. graminum and M. dirhodum in 2008. Nevertheless, in 2008, an increase in the abundance of E. connexa in the HPD system was observed earlier than in the LPD crop. This increase in the density of E. connexa did not result from an increase in the density of aphids (Figure 3). Eriopis connexa then reached its second highest density values at the end of November and the beginning of December, coincident with the highest abundance of $S$. avenae among the two management systems in 2007 and 2008. 


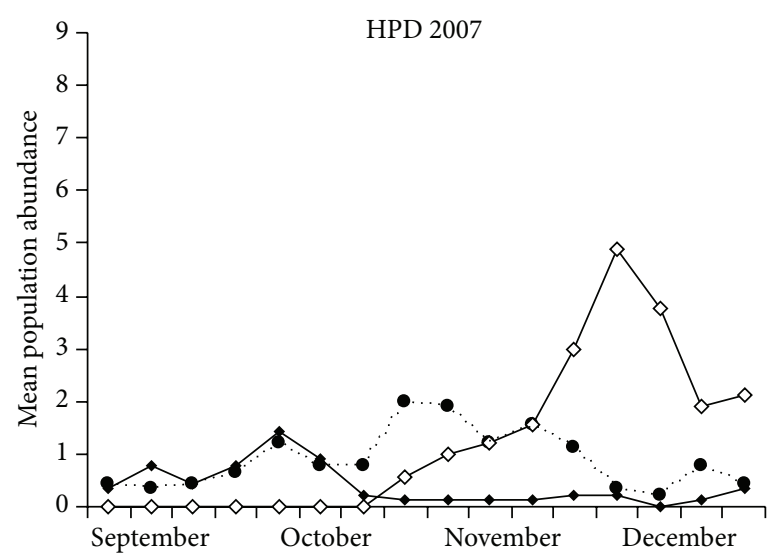

(a)

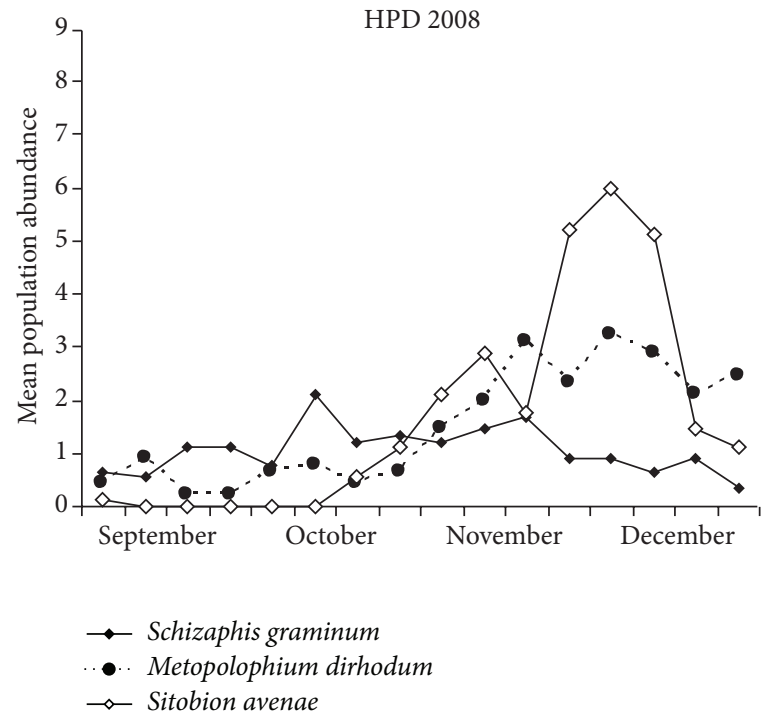

(c)

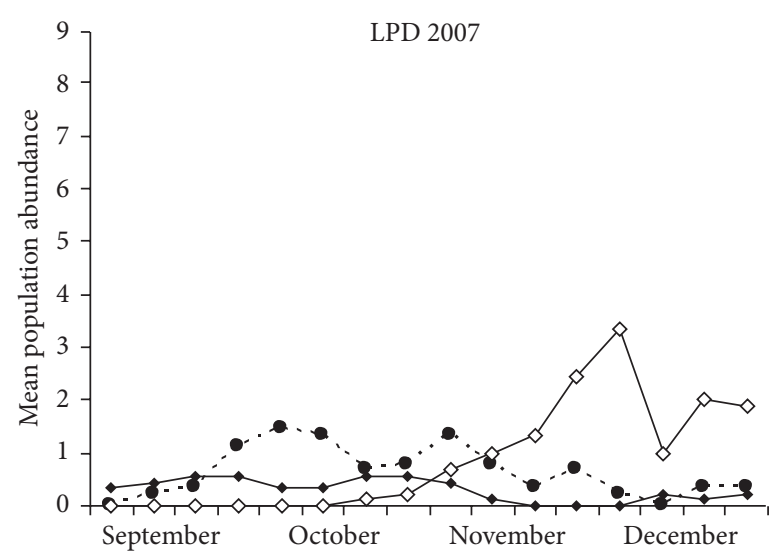

(b)

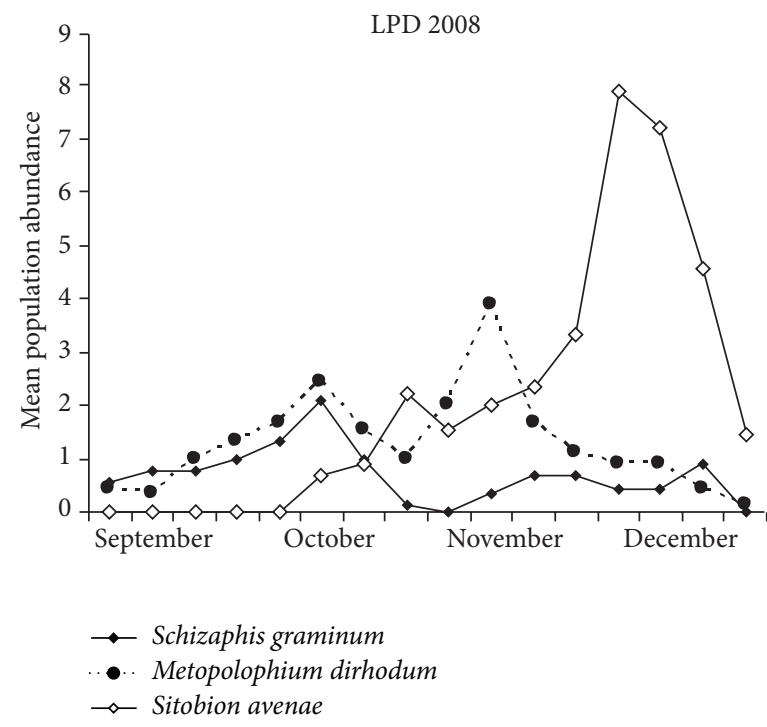

(d)

FIGURE 2: Mean population abundance of Schizaphis graminum, Metopolophium dirhodum, and Sitobion avenae in wheat crops with a high (HPD) and low plant diversity (LPD). Balcarce, 2007 and 2008.

Eriopis connexa showed a linear increase in its aggregational numerical response to aphid density, which varied in space and time. In both systems during 2007 and for LPD system during 2008, the abundance of E. connexa increased with an increasing abundance of aphids as indicated by positive and significant regression coefficients (Figure 4). In 2008, the linear regression model was only significant in LPD (Figure 4). Then, during 2008, E. connexa did not exhibit a numerical response to change in aphis density in HPD (Figure 4).

During 2007 (ANCOVA, $t$-test $=0.45$, N.S) and 2008 (ANCOVA, $t$-test $=0.17, \mathrm{~N} . \mathrm{S})$, there were no significant changes in the aggregational numerical response between management systems. However, in 2008, we registered an increase in the reproductive numerical response, which was greater for the HPD system (ANCOVA, $t$-test $=2.95, P<$ 0.05 ) (Figure 5). The presence of the first immature individuals was recorded at the end of October and at the beginning of September, and in both systems, the peak population of
E. connexa larvae was recorded in mid-November. Similar to adults of E. connexa, most immature individuals were found in the HPD area $\left(F_{1,7}=4.66, P<0.05\right)$ and there was no effect of weeks $\left(F_{6,7}=5.8\right.$, N.S). During this period, the number of larvae increased, but no superposition of different larval stages within these stages was registered.

\section{Discussion}

Our analysis of the population density of E. connexa and cereal aphids showed that trophic interactions in wheat fields varied greatly between years and depended on plant diversity surrounding the wheat crop. The results showed that increasing the structural complexity of the habitat surrounding wheat crops resulted in a higher abundance of E. connexa that would account for the smaller abundance of cereal aphids registered in the HPD systems. Similar conclusions were reached in previous studies, where the increase in plant diversity in wheat crops increased the number of larvae of 


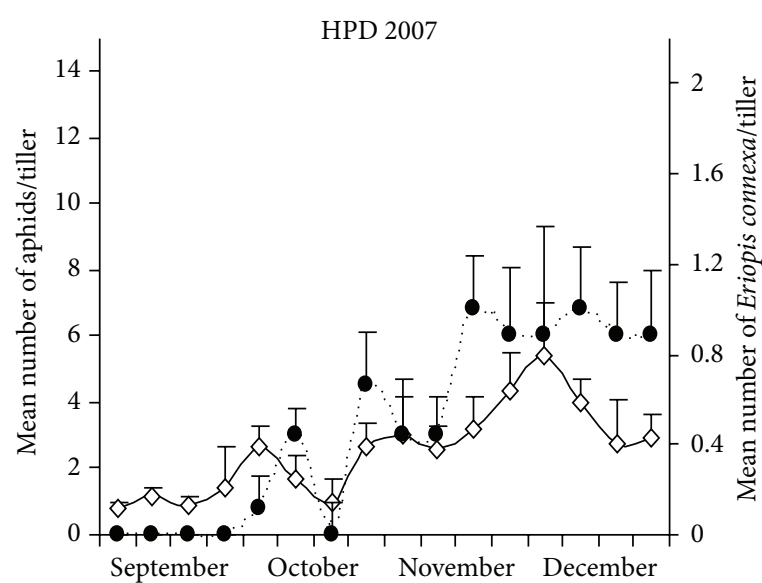

(a)

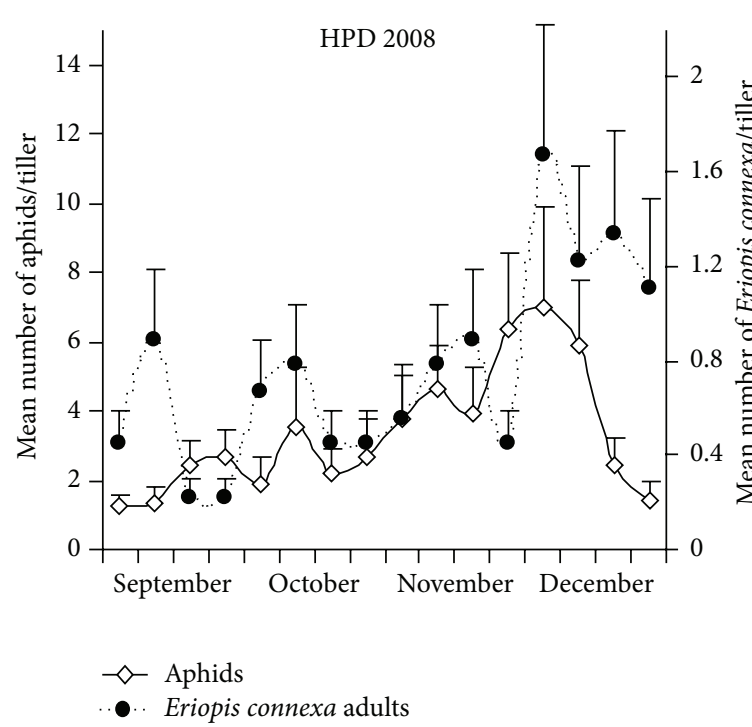

(c)

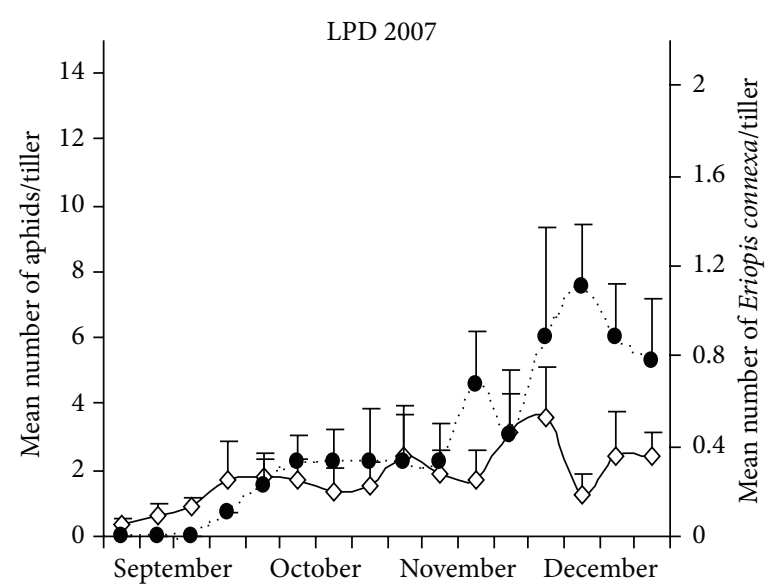

(b)

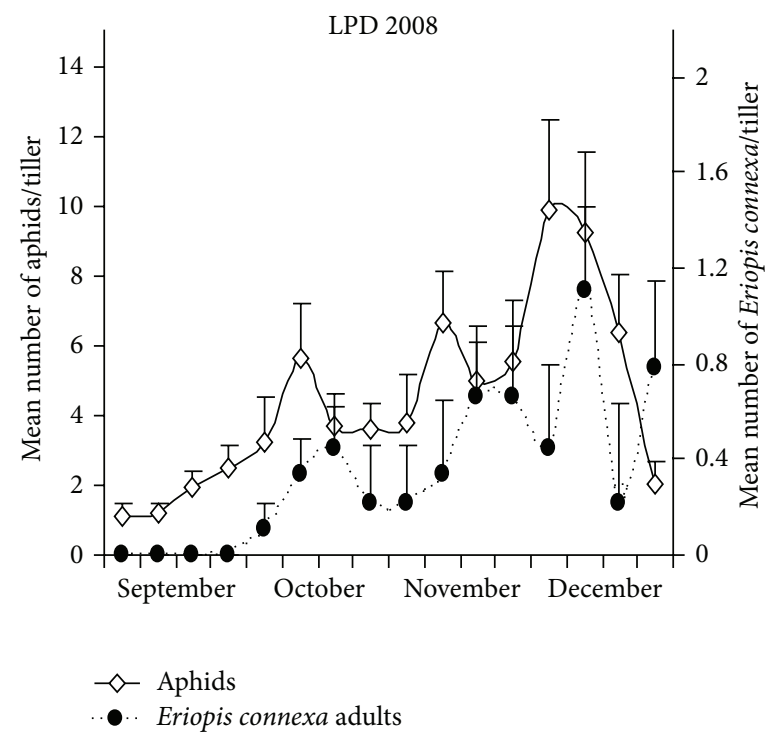

(d)

FIGURE 3: Seasonal abundance of aphid and adults of Eriopis connexa in wheat crops with a high (HPD) and low plant diversity (LPD). Balcarce, 2007 and 2008. Mean number of aphids per tiller \pm SE and mean number of Eriopis connexa per tiller \pm SE.

hoverflies and coccinellids [26] and aphid parasitism [34,37]. Studies in other crops likewise concluded that protecting the natural vegetation surrounding agroecosystems $[27,38]$ and/or introducing plant species into strips as a refuge are practices that increase natural enemy abundance in cultivated areas prone to pests $[13,20,30,31]$.

In the current study, the regression models indicated that adults and larvae of $E$. connexa were more abundant in wheat fields when aphids were abundant than when they were not. Unsurprisingly, the numerical responses of E. connexa were affected by cereal aphid abundance, but the most important results of this study support the view that E. connexa dynamics is not only exclusively related to prey abundance but also to plant diversity. The positive effect of plant diversity on the reproductive numerical response is a consequence of the dependence of emerged ladybeetles in early spring on prey in hibernation areas when aphid densities in the fields are still low. Since the level of food supply affects the fecundity
[39-41] and migration behavior of ladybeetles [39], the availability of aphids in noncrop landscape elements is likely to impact the numbers and distribution of ladybeetles and associated biocontrol in agro-ecosystems [13]. Moreover, prey availability in shelter habitats in early spring can influence postoverwintering mortality, the fecundity of surviving coccinellids, and the phenology of dispersal into the crop [42]. In this study, we registered this type of effect, because during 2008 , we recorded an increase in the abundance of E. connexa earlier in the HPD crop than in the LPD crop. This increase in the density of $E$. connexa did not result from an increase in the density of cereal aphids. Even if the abundance of cereal aphids could not account for that of E. connexa within this period, the presence of this coccinellid in the crops could be explained as a direct effect of the refuge strip. During the autumn of 2008, an increase in the abundance of aphids on $M$. sativa was observed. The presence of aphids in the refuges favored predator survival and increased their abundance 


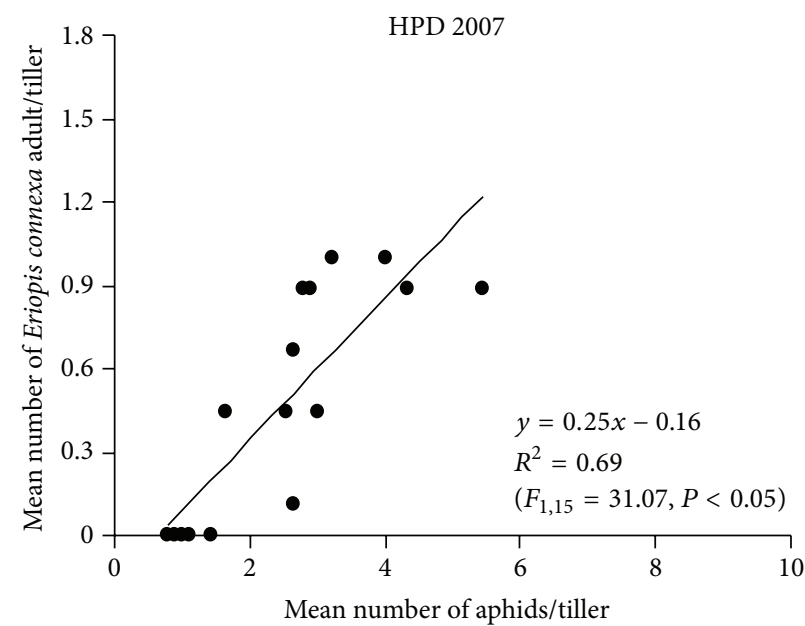

(a)

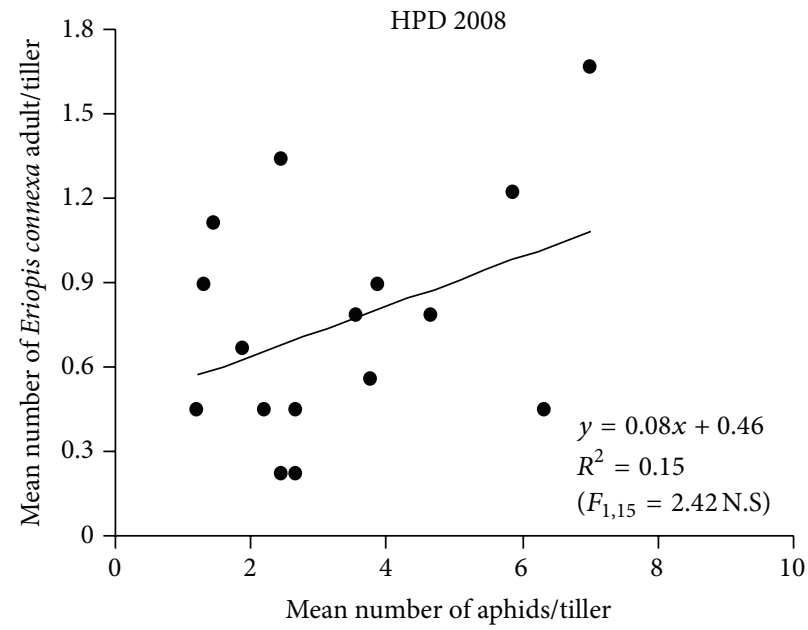

(c)

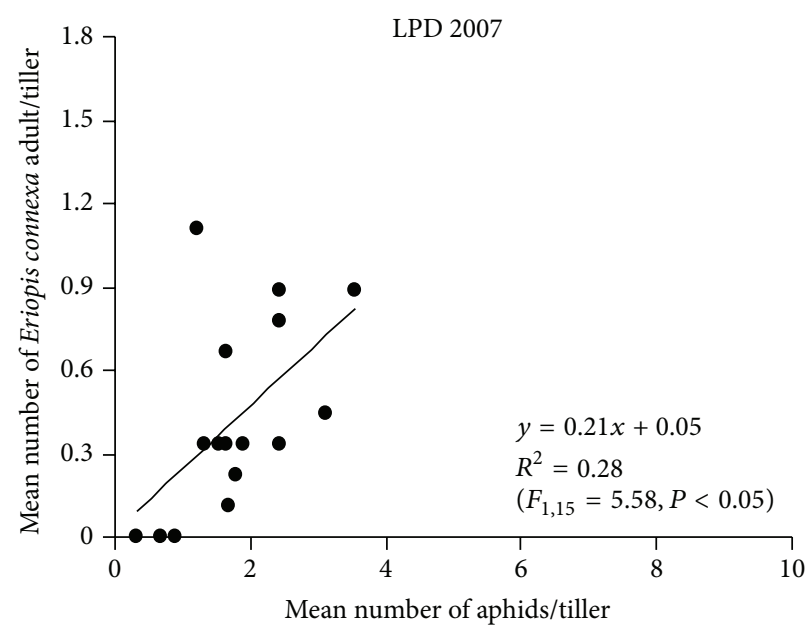

(b)

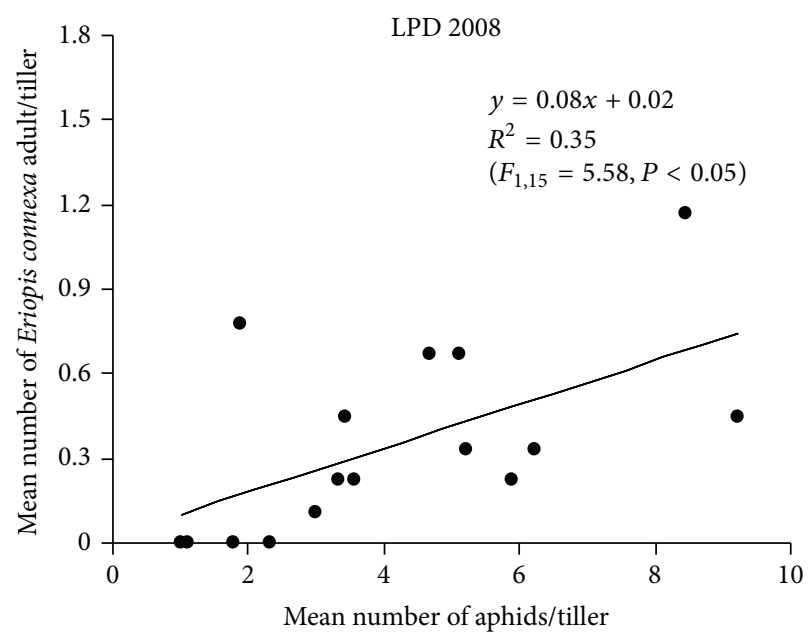

(d)

FIGURE 4: Aggregative numerical response of Eriopis connexa adults to variation in cereal aphid abundance in wheat crops with a high (HPD) and low plant diversity (LPD). Balcarce, 2007 and 2008.

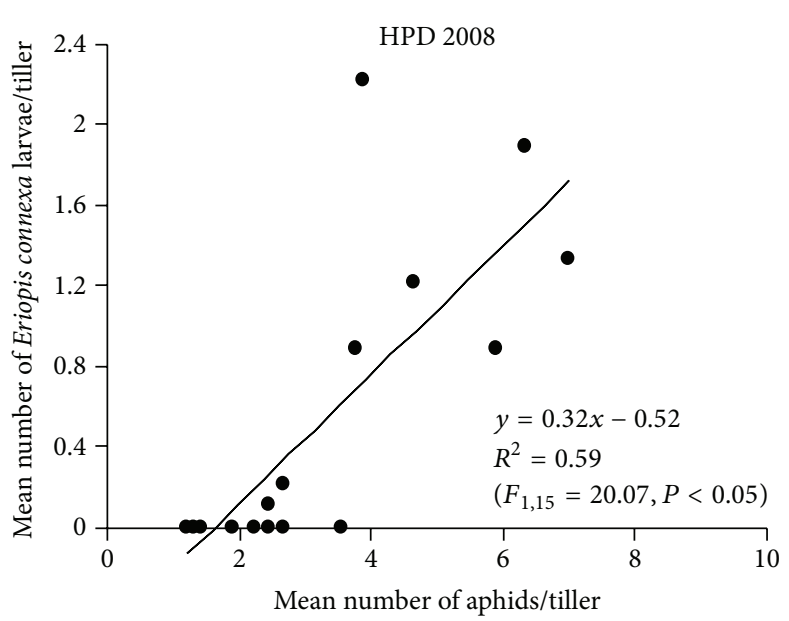

(a)

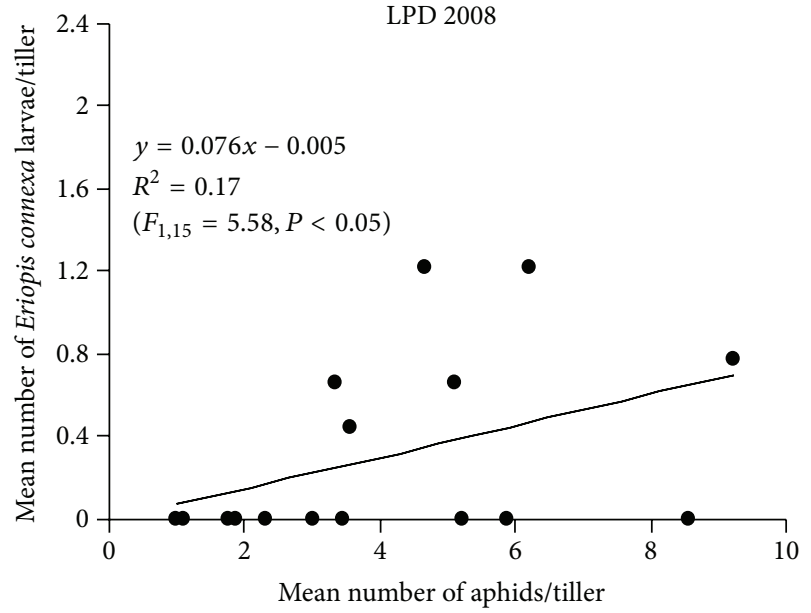

(b)

FIGURE 5: Reproductive numerical response of Eriopis connexa larvae to variation in cereal aphid abundance in wheat crops with a high (HPD) and low plant diversity (LPD). Balcarce, 2008. 
before the early stage of wheat sowing. Furthermore, the presence of aphids in the refuges could be explained by the better reproductive performance of adult $E$. connexa and, consequently, the presence of larvae during 2008. Egg production in aphidophaga is usually related solely to the availability of prey. However, some studies have indicated that fecundity is also influenced by the prey quality [43]. Our results are consistent with those of Bianchi and van der Werf [44], who established that reproduction and the associated control of pest aphids are affected by both the availability of nonpest aphids in noncrop habitats and the infestation date of pest aphids in wheat fields. When the infestation of wheat by pest aphids occurs early in the season, the prey availability of pest aphids alone is sufficient to allow $C$. septempunctata to attain its maximum reproduction. However, when the infestation by pest aphids is somewhat delayed, C. septempunctata becomes increasingly dependent on aphids in noncrop habitats. Therefore, prey availability in noncrop habitats might play a significant role in the conservation of ladybeetles and directly affect the numerical response of predators and consequently the biological control of cereal aphids in agroecosystems.

It might be possible to enhance the population of coccinellids in the agricultural landscape by increasing plant diversity. Plant diversity supports prey diversity and provides refuge and additional resources such as pollen and nectar fecundity $[13,31-33]$. As a result, coccinellids and other natural enemies should be able to respond better to the change in aphid densities in diverse habitats. In agricultural landscapes, it might be possible to enhance populations of coccinellids by manipulating plant diversity. The presence of refuges near wheat crops is particularly important in determining the local abundance of $E$. connexa. The augmentation of prey availability in noncrop habitats is one of the habitat management strategies that might preserve predators in agricultural landscapes and increase their effectiveness [13]. Moreover, individual predators might not need to travel far to obtain essential resources. This suggests that the potential of E. connexa as a predator of cereal aphids also increases directly in proportion to landscape vegetal diversity.

\section{Conclusions}

In summary, we observed an increase in the numerical response of E. connexa in an HPD system as measured by an increase in their abundance, reproduction, and early seasonal activity. For E. connexa, we demonstrated that enhancing plant diversity can result in an increase in the population abundance of this coccinellid predator. Even though an increase in plant diversity in the agroecosystems and its maintenance represents an additional cost for farmers, predator efficacy would increase over time and consequently, pest attack would be less likely to cause economically important damage.

\section{Acknowledgments}

The authors are grateful to the editor Jean-Guy Godin and one anonymous reviewer for the valuable comments on earlier drafts of this paper.

\section{References}

[1] V. O. Sadras, A. Fereres, and R. H. Ratcliffe, "Wheat growth, yield and quality as affected by insect herbivores," in Wheat: Ecology and Physiology of Yield Determination, E. H. Satorre and G. A. Slafer, Eds., pp. 183-211, Food Products Press, The Haworth Press, Binghamton, NY, USA, 1999.

[2] H. F. van Emden and R. Harrington, Eds., Aphids as Crop Pests, CABI, Wallingford, UK, 2007.

[3] R. H. Quintanilla, Pulgones: Características morfológicas y biológicas: Especies de mayor importancia agrícola, Hemisferio Sur, Buenos Aires, Argentina, 1976.

[4] A. M. Vincini, A. N. López, and D. Sisti, Presencia del "pulgón de la avena" Rophalosiphum padi en el sudeste bonaerense, IPE, Prod. Veg. INTA, Balcarce, Argentina, 1982.

[5] R. L. Carrillo, M. Z. Mellazo, and A. B. Pino, "Los áfidos Sitobium avenae (Fabricius) y Metopolophium dirhodum (Walk). $\mathrm{Su}$ influencia en el rendimiento, ubicación en la planta y sus enemigos naturales," Agro Sur, vol. 2, no. 2, pp. 71-85, 1974.

[6] C. Torres, C. Senigagliesi, R. Parisi, and A. Mottioli, "Incidencia del pulgón amarillo de los cereales Metopolophium dirhodum Walk en el cultivo de Trigo," Informe Técnico 134, INTA, Estación experimental, 1976.

[7] G. Lee, D. J. Stevens, S. Stokes, and S. D. Wratten, "Duration of cereal aphid populations and the effects on wheat yield and breadmaking quality," Annals of Applied Biology, vol. 98, no. 2, pp. 169-178, 1981.

[8] P. R. Holmes, "A field study of the predators of the grain aphid, Sitobion avenae (F.) ( Hemiptera: Aphididae), in winter wheat in Britain," Bulletin of Entomological Research, vol. 74, no. 4, pp. 623-631, 1984.

[9] R. W. Kieckhefer and B. H. Kantack, "Yield losses in winter grains caused by cereal aphids (Homoptera: Aphididae) in South Dakota," Journal of Economic Entomology, vol. 81, pp. 317321, 1988

[10] R. W. Kieckhefer and J. L. Gellner, "Yield losses in winter wheat caused by low-density cereal aphid populations," Agronomy Journal, vol. 84, no. 2, pp. 180-183, 1992.

[11] J. N. Oakley and K. F. A. Walters, "A field evaluation of different criteria for determining the need to treat winter wheat against the grain aphid Sitobion avenae and the rose-grain aphid Metopolophium dirhodum," Annals of Applied Biology, vol. 124, no. 2, pp. 195-211, 1994.

[12] R. G. van Driesche and T. S. Bellows, Biological Control, Chapman \& Hall, New York, NY, USA, 1996.

[13] D. Landis, F. D. Menalled, J. Lee, D. M. Carmona, and A. P. Valdez, "Habitat management to enhance biological control in IPM," in Emerging Technologies for Integrated Pest Management: Concepts, Research and Implementation, G. G. Kenedy and T. B. Sutton, Eds., pp. 226-239, APS Press, St. Paul, Minn, USA, 2000.

[14] A. E. Hajek, "Why use natural enemies?" in Natural Enemies: An Introduction to Biological Control, pp. 3-18, Cambridge University Press, Cambridge, UK, 2004.

[15] A. K. Fiedler, D. A. Landis, and S. D. Wratten, "Maximizing ecosystem services from conservation biological control: the role of habitat management," Biological Control, vol. 45, no. 2, pp. 254271, 2008.

[16] C. Salto, J. Lopez, I. Bertolaccini, and J. Imwinkelried, "Observaciones preliminares de las interacciones malezas-fitófagosenemigos naturales en el área central de la Provincia de Santa Fe," Gaceta Agronómica, vol. 12, no. 71, pp. 21-30, 1993. 
[17] M. J. Brewer and N. C. Elliott, "Biological control of cereal aphids in North America and mediating efects of host plant and habitat manipulations," Annual Review of Entomology, vol. 49, pp. 219-242, 2004.

[18] J. J. Obrycki and T. J. Kring, "Predaceous coccinellidae in biological control," Annual Review of Entomology, vol. 43, pp. 295-321, 1998.

[19] E. D. Saini, "Presencia de Harmonia axyridis (Pallas) (Coleoptera: Coccinellidae) en la provincia de Buenos Aires," Aspectos Biológicos y Morfológicos. RIA, vol. 33, no. 1, pp. 151-160, 2004.

[20] G. Martinoia, Fluctuación poblacional de pulgones (Hemiptera: Aphididae) y sus reguladores naturales (Coleoptera: Coccinellidae) en cultivos de papa con refugios vegetales y uso oportuno de plaguicidas [Tesis Magister Scientiae], Facultad de Ciencias Agrarias, Universidad Nacional de Mar del Plata, Balcarce, Argentina, 2008.

[21] J. E. Gyenge, J. D. Edelstein, and C. E. Salto, "Efectos de la temperatura y la dieta en la biología de Eriopis connexa (Germar) (Coleoptera: Coccinellidae)," Anais da Sociedade Entomológica do Brasil, vol. 27, no. 3, pp. 345-356, 1998.

[22] E. D. Saini and O. R. de Coll, "Clave para la identificación de los coccinélidos (Coleoptera) encontrados en yerba mate," RIA, vol. 27, no. 2, pp. 231-241, 1996.

[23] S. Eizaguirre, "Nueva especie del género Eriopis (Coleoptera: Coccinellidae)," Boletín de la SEA, no. 35, pp. 47-49, 2004.

[24] C. S. Holling, "Principles of insect predation," Annual Review of Entomology, vol. 6, pp. 163-182, 1961.

[25] E. W. Evans, "Searching and reproductive behaviour of female aphidophagous ladybirds (Coleoptera: Coccinellidae): a review," European Journal of Entomology, vol. 100, no. 1, pp. 1-10, 2003.

[26] I. Bertolaccini, P. Andrada, and O. Quaino, "Efecto de franjas marginales en la atracción de Coccinellidae y Syrphidae, depredadores de áfidos en trigo, en la zona central de la provincia de Santa Fe, Argentina," Agronomía Tropical, vol. 58, no. 3, pp. 267-276, 2008.

[27] J. P. Harmon, A. R. Ives, J. E. Losey, A. C. Olson, and K. S. Rauwald, "Coleomegilla maculata (Coleoptera: Coccinellidae) predation on pea aphids promoted by proximity to dandelions," Oecologia, vol. 125, no. 4, pp. 543-548, 2000.

[28] J. Lys and W. Nentwig, "Augmentation of beneficial arthropods by strip-management-4. Surface activity, movements and activity density of abundant carabid beetles in a cereal field," Oecologia, vol. 92, no. 3, pp. 373-382, 1992.

[29] J. A. Lys and W. Nentwig, "Improvement of the overwintering sites for Carabidae, Staphylinidae and Araneae by stripmanagement in a cereal field," Pedobiología, vol. 38, no. 3, pp. 238-242, 1994.

[30] D. M. Carmona and D. A. Landis, "Influence of refuge habitats and cover crops on seasonal activity-density of ground beetles (Coleoptera: Carabidae) in field crops," Environmental Entomology, vol. 28, no. 6, pp. 1145-1153, 1999.

[31] M. Jonsson, S. D. Wratten, D. A. Landis, and G. M. Gurr, "Recent advances in conservation biological control of arthropods by arthropods," Biological Control, vol. 45, no. 2, pp. 172-175, 2008.

[32] M. M. Gardiner, D. A. Landis, C. Gratton et al., "Landscape diversity enhances biological control of an introduced crop pest in the North-Central USA," Ecological Applications, vol. 19, no. 1, pp. 143-154, 2009.
[33] R. Isaacs, J. Tuell, A. Fiedler, M. Gardiner, and D. Landis, "Maximizing arthropod-mediated ecosystem services in agricultural landscapes: the role of native plants," Frontiers in Ecology and the Environment, vol. 7, no. 4, pp. 196-203, 2009.

[34] K. Ma, S. Hao, H. Zhao, and L. Kang, "Strip cropping wheat and alfalfa to improve the biological control of the wheat aphid Macrosiphum avenae by the mite Allothrombium ovatum," Agriculture, Ecosystems and Environment, vol. 119, no. 1-2, pp. 49-52, 2007.

[35] M. P. Díaz and C. G. Demétrio, Introducción a los Modelos Lineales Generalizados. Su Aplicación a las Ciencias Biológicas, Screen Edit, Córdoba, Spain, 1998.

[36] SAS Institute Inc., SAS/STAT 9.2 User's Guide, SAS Institute Inc., Cary, NC, USA, 2008, http://support.sas.com/documentation/ $\mathrm{cdl} /$ en/statuggenmod/61787/PDF/default/statuggenmod.pdf.

[37] A. Langer and T. Hance, "Enhancing parasitism of wheat aphids through apparent competition: a tool for biological control," Agriculture, Ecosystems and Environment, vol. 102, no. 2, pp. 205-212, 2004.

[38] R. Beltrame and C. Salto, "Ammi majus L. y Foeniculum vulgare Miller como hospedantes de afidos y sus enemigos naturales," Revista de la Facultad de Agronomía, Universidad Nacional Buenos Aires, vol. 20, no. 3, pp. 395-400, 2000.

[39] A. Ferran and A. F. G. Dixon, "Foraging behaviour of ladybird larvae (Coleoptera: Coccinellidae)," European Journal of Entomology, vol. 90, no. 4, pp. 383-402, 1993.

[40] A. F. G. Dixon and Y. Guo, "Egg and cluster size in ladybird beetles (Coleoptera: Coccinellidae): the direct and indirect effects of aphid abundance," European Journal of Entomology, vol. 90, pp. 457-463, 1993.

[41] J. Y. Xia, W. van der Werf, and R. Rabbinge, “Temperature and prey density on bionomics of Coccinella septempunctata (Coleoptera: Coccinellidae) feeding on Aphis gossypii (Homoptera: Aphididae) on cotton," Environmental Entomology, vol. 28, no. 2, pp. 307-314, 1999.

[42] G. J. K. Griffiths, J. M. Holland, A. Bailey, and M. B. Thomas, "Efficacy and economics of shelter habitats for conservation biological control," Biological Control, vol. 45, no. 2, pp. 200 209, 2008.

[43] J. L. Hemeptine, A. F. G. Dixon, J. L. Doucet, and J. E. Petersen, "Optimal foraging by hoverflies (Diptera: Syrphidae) and ladybird (Coleptera: Coccinellidae): mechanimisms," European Journal of Entomology, vol. 90, pp. 451-455, 1993.

[44] F. J. J. A. Bianchi and W. van der Werf, "Model evaluation of the function of prey in non-crop habitats for biological control by ladybeetles in agricultural landscapes," Ecological Modelling, vol. 171, no. 1-2, pp. 177-193, 2004. 

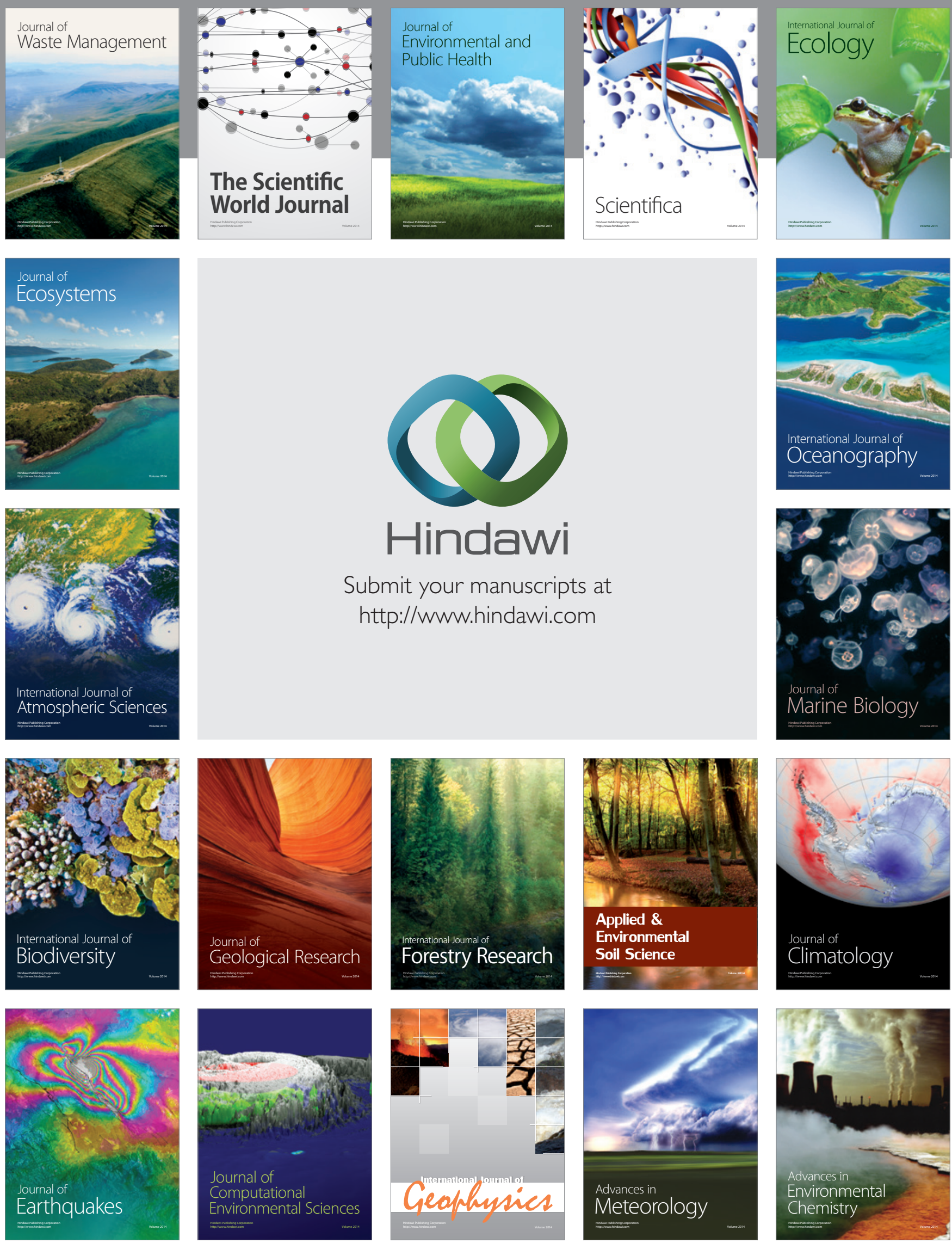